\title{
Association Between Prostate Cancer and 25-Hydroxyvitamin D2 Levels: National Health and Nutrition Examination Survey 2007-2008 Results
}

\author{
Jee Soo Park, Won Sik Jang, Sung Joon Hong, Young Deuk Choi, \\ Koon Ho Rha, Won Sik Ham
}

Department of Urology and Urological Science Institute,

Yonsei University College of Medicine, Seoul, Korea

\begin{abstract}
Purpose: To report an association between prostate cancer and vitamin $D$ levels among different races in a single population in the United States.

Materials and Methods: We investigated whether there was an association between vitamin $\mathrm{D}$ level and prostate cancer in different races in the United States. We used data collected from 1,363 men during the National Health and Nutrition Examination Survey 2007-2008. Multivariate logistic regression analysis was used to evaluate the independent associations between vitamin $D$ levels (not only 25-hydroxyvitamin $D[25(\mathrm{OH}) \mathrm{D}]$, but also $25(\mathrm{OH}) \mathrm{D} 2$ and D3) and prostate cancer. Association between vitamin D levels and prostate specific antigen level was also analyzed in non-Hispanic white males without prostate cancer.

Results: Older age was significantly associated with prostate cancer in all races $(p<0.05)$, whereas vitamin $D$ $(p=0.024)$, especially $25(\mathrm{OH}) \mathrm{D} 2(p=0.027)$ was significantly higher only in non-Hispanic white males. There was no difference in vitamin $D$ levels between non-Hispanic white males with a prostate specific antigen concentration $>3 \mathrm{ng} / \mathrm{mL}$ and $\leq 3 \mathrm{ng} / \mathrm{mL}$.

Conclusions: This study revealed a positive association between vitamin $\mathrm{D}$, especially $25(\mathrm{OH}) \mathrm{D} 2$, and prostate cancer only in non-Hispanic white males. And vitamin $D$ was not associated with prostate specific antigen level causing detection bias. (Korean J Urol Oncol 2020;18:32-39)
\end{abstract}

Key Words: Prostate cancer $\cdot$ Vitamin D $\cdot$ Age $\cdot$ Prostate specific antigen

\section{INTRODUCTION}

Prostate cancer is the most common malignant cancer affecting adult males in the United States, but the etiological

Received November 18, 2019, Revised December 4, 2019,

Accepted December 9, 2019

Corresponding Author: Won Sik Ham

Department of Urology and Urological Science Institute, Yonsei University College of Medicine, 50-1 Yonsei-ro, Seodaemun-gu, Seoul 03722, Korea

E-mail: uroham@yuhs.ac

Tel: +82-2-2228-2310, Fax: +82-2-312-2538

ORCID: https://orcid.org/0000-0003-2246-8838 factors for prostate cancer are not completely understood. Vitamin D is a fat-soluble vitamin produced by exposure to sunlight or obtained from the diet. The biological functions of vitamin D include participation in bone metabolism and remodeling and antiproliferative and antiangiogenic effects. ${ }^{1}$ Many studies have revealed that vitamin D has protective effects against the development of prostate cancer. ${ }^{2-4}$ However, the results of a recent meta-analysis suggest that there is a positive association between higher levels of vitamin $\mathrm{D}$ and prostate cancer risk. ${ }^{5}$

Vitamin D levels are affected by skin pigmentation, which differs according to race. Levels of vitamin $\mathrm{D}$ are

This is an Open Access article distributed under the terms of the Creative Commons Attribution Non-Commercial License (http://creativecommons.org/licenses/by-nc/4.0/) which permits unrestricted non-commercial use, distribution, and reproduction in any medium, provided the original work is properly cited. 2020 (C) Copyright The Korean Urological Oncology Society and The Korean Prostate Society. All Rights Reserved. 
also determined by diet, which differs between and within Western and Asian populations. In the United States, the incidence rates of prostate cancer are $70 \%$ greater in African American compared with non-Hispanic white populations. African American populations have lower mean circulating 25-hydroxyvitamin D levels. ${ }^{6}$

We investigated whether there was association between vitamin D status, which was assessed using serum 25-hydroxyvitamin D $(25(\mathrm{OH}) \mathrm{D})$ concentrations, and prostate cancer in different races. We used data from the National Health and Nutrition Examination Survey (NHANES) 2007-2008 for the analysis.

\section{MATERIALS AND METHODS}

\section{Study Population}

The NHANES is an ongoing cross-sectional observational study that collects health-related information using multistage probability sampling of the civilian, non-institutionalized United States population. The Institutional Review Board of the National Center for Health Statistics approved the protocol for the NHANES. Informed consent was obtained from all participants. We used data obtained from male participants ( $\geq 40$ years of age), which was obtained during the 2007-2008 NHANES cycle.

NHANES datasets can be downloaded at NHANES website (https://wwwn.cdc.gov/nchs/nhanes). The questionnaires, data sets, and related documentation page lists all the survey cycles from the most recent to most historic. We used the current NHANES, also known as continuous NHANES, which refers to the 2-year cycles of data produced since 1999. Each cycle is divided into 5 sections labeled by collection method: demographics, dietary, examination, laboratory, and questionnaire. We could select specific variables to be included in our analysis by downloading specific files. All information regarding which files contain specific variables are listed on documentation files.

\section{Measurement and Classification of Variables}

Serum 25(OH)D metabolites were measured at a Centers for Disease Control laboratory using the Diasorin assay. The total serum $25(\mathrm{OH}) \mathrm{D}(\mathrm{nmol} / \mathrm{L})$ concentration was calculated as the sum of $25(\mathrm{OH}) \mathrm{D} 3$ and $25(\mathrm{OH}) \mathrm{D} 2$, excluding the C3-epi-25(OH)D3 metabolite. Vitamin D data were col- lected as part of the NHANES in the southern United States during the winter months and in the northern United States during the summer months. Serum total cholesterol concentration was measured using an enzyme-based assay. In the men diagnosed with prostate cancer, all variables were measured after the diagnosis of prostate cancer. Since prostate specific antigen (PSA) varies with treatments, PSA was not evaluated in those with prostate cancer or prostatitis. Men who had prostate manipulation (e.g., prostate biopsy, surgery, or cystoscopy) within 1 month or rectal examination within 1 week were also excluded from PSA evaluation. The serum total PSA level was measured using the Hybritech method (Beckman Access, Fullerton, CA, USA).

Body mass index (BMI) was calculated as body weight in kilograms divided by height in meters squared. Dietary calcium and vitamin D intake amounts were based on a single 24-hour dietary recall.

\section{Subgroup Analysis}

Each participant was assigned by race to one of 3 groups (i.e., non-Hispanic white, non-Hispanic black, and Others [e.g., Mexican American and Hispanic]). There were limited numbers of participants in the non-White race groups. Therefore, the vitamin D and PSA subgroups were confined to the non-Hispanic white group. The vitamin D intervals were taken from Tuohimaa et al., ${ }^{7}$ who described the U-shape of prostate cancer risk. The PSA cut point of 3.0 $\mathrm{ng} / \mathrm{mL}$ was set using National Comprehensive Cancer Network guidelines ${ }^{8}$ and subgroup analysis by PSA was done on only non-Hispanic white males without prostate cancer, and who have PSA results available.

\section{Statistical Analysis}

The results were reported as mean (standard deviation) values for continuous variables and as percentage values for categorical variables. For the univariate analysis, t-tests and analysis of variance were used to compare continuous variables. A multivariate logistic regression model was used to evaluate the association between prostate cancer and vitamin D level after adjusting for potential confounding factors that were related to an increased prostate cancer risk. We used multivariate models of logistic regression that included all risk factors that were revealed to be statistically significant by the univariate analysis and evaluated odds ratios 
(ORs) by adjusting for potential confounders using a series of models. In the non-Hispanic white males without prostate cancer, multivariate logistic regression model was used to explain the relationship between PSA $>3 \mathrm{ng} / \mathrm{mL}$ and other variables in the same way.

IBM SPSS Statistics ver. 23.0 (IBM Co., Armonk, NY, USA) was used for the statistical analyses. All statistical tests were two-tailed, and a p-value $<0.05$ was considered to indicate a statistically significant result.

\section{RESULTS}

The baseline characteristics of the study population are presented in Table 1. Among the 1,363 participants, 55.6\% were non-Hispanic white. The percent who had a prostate cancer diagnosis in the non-Hispanic white group was $6.3 \%$ compared with $10.2 \%$ in the non-Hispanic black group. There were no differences in BMI between the 3 groups. The distribution in vitamin $\mathrm{D}$ level indicated that most of the non-Hispanic white males had adequate levels of vitamin D (i.e., $\geq 20 \mathrm{ng} / \mathrm{mL}$ [49.9 nmol/L], Institute of Medicine). ${ }^{9}$ Consistent with previous study results, vitamin D levels were significantly lower in the non-Hispanic black group compared with the other races. ${ }^{6}$ The groups with vitamin D levels $<40 \mathrm{nmol} / \mathrm{L}$ had no prostate cancer compared with the groups with vitamin D levels $\geq 40 \mathrm{nmol} / \mathrm{L}$ (Table 2).

The results of the univariate and multivariate analyses in- dicated that non-Hispanic whites with a prostate cancer were significantly older and had higher 25(OH)D2 levels compared to those without a prostate cancer (Table 3). Older age was significantly associated with prostate cancer in the group of non-Hispanic blacks. However, 25(OH)D2 and $25(\mathrm{OH}) \mathrm{D} 3$ levels were not associated with prostate cancer (Table 4). Also, in the Others group, the results of univariate and multivariate analyses revealed that older age was significantly associated with prostate cancer (Table 5).

Among 710 non-Hispanic white males without prostate cancer, 688 men who have PSA results available were included in the subgroup analysis by PSA. The results of the univariate analysis indicated that the members of the non-Hispanic white group with a PSA level $>3 \mathrm{ng} / \mathrm{mL}$ were significantly older and had lower body weights, lower calcium intakes, and higher 25(OH)D2 levels compared with those with PSA levels $\leq 3 \mathrm{ng} / \mathrm{mL}$. However, age was the only statistically significant factor in the multivariate analysis (Table 6).

\section{DISCUSSION}

The results of our analysis indicated that in non-Hispanic white males, higher vitamin D levels were significantly and independently associated with prostate cancer, even after adjustment for multiple potential confounding variables. To the best of our knowledge, this study of a United States

Table 1. Characteristics of the study population

\begin{tabular}{|c|c|c|c|c|}
\hline \multirow{2}{*}{ Characteristic } & \multicolumn{3}{|c|}{ Race } & \multirow{2}{*}{ p-value ${ }^{\dagger}$} \\
\hline & White $^{\dagger}(\mathrm{n}=758)$ & Black $^{\dagger}(\mathrm{n}=256)$ & Others $^{\dagger}(n=349)$ & \\
\hline Age (yr) & $62.8 \pm 12.7$ & $59.2 \pm 10.9$ & $57.3 \pm 11.5$ & $<0.001$ \\
\hline Weight $(\mathrm{kg})$ & $90.2 \pm 19.1$ & $89.9 \pm 21.5$ & $83.0 \pm 15.8$ & $<0.001$ \\
\hline Body mass index $\left(\mathrm{kg} / \mathrm{m}^{2}\right)$ & $29.1 \pm 5.5$ & $29.2 \pm 6.5$ & $29.1 \pm 4.6$ & 0.997 \\
\hline Total cholesterol (mg/dL) & $190.4 \pm 41.4$ & $198.2 \pm 41.3$ & $205.1 \pm 42.0$ & $<0.001$ \\
\hline Calcium (mg/day)* & $954.8 \pm 568.3$ & $737.8 \pm 471.7$ & $903.6 \pm 570.9$ & $<0.001$ \\
\hline Vitamin D $(25(\mathrm{OH}) \mathrm{D} 2+25(\mathrm{OH}) \mathrm{D} 3)^{*}(\mu \mathrm{g} /$ day $)$ & $4.9 \pm 5.4$ & $3.6 \pm 5.9$ & $4.7 \pm 4.6$ & 0.004 \\
\hline $25(\mathrm{OH}) \mathrm{D}(\mathrm{nmol} / \mathrm{L})$ & $71.3 \pm 20.7$ & $44.5 \pm 18.4$ & $58.3 \pm 17.6$ & $<0.001$ \\
\hline 25(OH)D2 (nmol/L) & $5.6 \pm 9.4$ & $4.5 \pm 8.3$ & $3.5 \pm 6.0$ & 0.001 \\
\hline 25(OH)D3 (nmol/L) & $65.7 \pm 21.2$ & $40.0 \pm 17.7$ & $54.8 \pm 17.2$ & $<0.001$ \\
\hline Prostate cancer & $48(6.3)$ & $26(10.2)$ & $5(1.4)$ & $<0.001$ \\
\hline
\end{tabular}

Values are presented as mean \pm standard deviation or number (\%).

25(OH)D2: 25-hydroxyvitamin D2, 25(OH)D3: 25-hydroxyvitamin D3.

*Calcium and vitamin D indicate the amount taken by the diet. ${ }^{\dagger}$ These include those with prostate cancer and those without.

${ }^{\ddagger} \mathrm{p}$-value calculated using analysis of variance. 
Table 2. Characteristics of non-Hispanic white males by categories of vitamin D level

\begin{tabular}{|c|c|c|c|c|c|c|}
\hline \multirow{2}{*}{ Characteristic } & \multicolumn{5}{|c|}{ Non-Hispanic White $(\mathrm{n}=758)$} & \multirow{2}{*}{ p-value ${ }^{\dagger}$} \\
\hline & $\leq 19(\mathrm{n}=2)$ & $20-39(n=34)$ & $40-59 \quad(n=180)$ & $60-79(n=308)$ & $\geq 80 \quad(n=234)$ & \\
\hline Age (yr) & $70.0 \pm 14.1$ & $61.8 \pm 9.8$ & $62.2 \pm 13.1$ & $63.0 \pm 13.1$ & $63.0 \pm 12.2$ & 0.841 \\
\hline Weight $(\mathrm{kg})$ & $112.1 \pm 43.2$ & $93.6 \pm 25.7$ & $92.7 \pm 20.2$ & $90.3 \pm 18.2$ & $87.3 \pm 17.6$ & 0.015 \\
\hline Body mass index $\left(\mathrm{kg} / \mathrm{m}^{2}\right)$ & $34.2 \pm 11.6$ & $30.6 \pm 8.1$ & $29.9 \pm 5.3$ & $29.2 \pm 5.2$ & $28.2 \pm 5.1$ & 0.005 \\
\hline Total cholesterol (mg/dL) & $176.5 \pm 5.0$ & $193.3 \pm 49.2$ & $187.8 \pm 43.0$ & $190.0 \pm 40.1$ & $192.5 \pm 41.0$ & 0.779 \\
\hline Calcium (mg/day)* & $670.5 \pm 430.6$ & $912.2 \pm 668.2$ & $873.9 \pm 479.4$ & $962.1 \pm 560.6$ & $1,015.9 \pm 620.3$ & 0.130 \\
\hline $\begin{array}{r}\text { Vitamin D }(25(\mathrm{OH}) \mathrm{D} 2+ \\
25(\mathrm{OH}) \mathrm{D} 3)^{*}(\mu \mathrm{g} / \text { day })\end{array}$ & $2.7 \pm 1.7$ & $3.4 \pm 3.7$ & $4.1 \pm 3.7$ & $5.0 \pm 6.1$ & $4.9 \pm 5.4$ & 0.017 \\
\hline $25(\mathrm{OH}) \mathrm{D}(\mathrm{nmol} / \mathrm{L})$ & $1.5 \pm 0.0$ & $1.6 \pm 0.4$ & $3.8 \pm 5.9$ & $5.8 \pm 9.0$ & $7.2 \pm 12.0$ & $<0.001$ \\
\hline 25(OH)D2 (nmol/L) & $13.6 \pm 4.5$ & $28.8 \pm 4.9$ & $47.7 \pm 7.6$ & $63.7 \pm 10.5$ & $87.9 \pm 17.3$ & $<0.001$ \\
\hline 25(OH)D3 (nmol/L) & $0(0)$ & $0(0)$ & $10(5.6)$ & $17(5.5)$ & $21(9.0)$ & 0.222 \\
\hline
\end{tabular}

Values are presented as mean \pm standard deviation or number (\%).

25(OH)D2: 25-hydroxyvitamin D2, 25(OH)D3: 25-hydroxyvitamin D3.

*Calcium and vitamin D indicate the amount taken by the diet. ${ }^{\dagger} \mathrm{p}$-value calculated using analysis of variance.

Table 3. Characteristics of non-Hispanic white males by prostate cancer history

\begin{tabular}{|c|c|c|c|c|c|}
\hline Characteristic & $\begin{array}{l}\text { Never been diagnosed } \\
\text { with prostate cancer } \\
\qquad(\mathrm{n}=710)\end{array}$ & $\begin{array}{l}\text { Diagnosed with } \\
\text { prostate cancer } \\
\qquad(\mathrm{n}=48)\end{array}$ & p-value ${ }^{\dagger}$ & p-value ${ }^{\ddagger}$ & OR $(95 \% \mathrm{CI})$ \\
\hline Age (yr) & $62.0 \pm 12.6$ & $74.4 \pm 6.8$ & $<0.001$ & $<0.001$ & \\
\hline Weight $(\mathrm{kg})$ & $90.4 \pm 19.2$ & $87.1 \pm 16.4$ & 0.257 & & \\
\hline Body mass index $\left(\mathrm{kg} / \mathrm{m}^{2}\right)$ & $29.2 \pm 5.6$ & $28.4 \pm 4.2$ & 0.344 & & \\
\hline Total cholesterol (mg/dL) & $190.7 \pm 41.5$ & $184.9 \pm 39.2$ & 0.345 & & \\
\hline Calcium (mg/day)* & $955.9 \pm 571.6$ & $938.0 \pm 522.9$ & 0.833 & & \\
\hline $\begin{array}{l}\text { Vitamin D }(25(\mathrm{OH}) \mathrm{D} 2+25(\mathrm{OH}) \mathrm{D} 3)^{*} \\
(\mu \mathrm{g} / \text { day })\end{array}$ & $4.9 \pm 5.5$ & $4.8 \pm 3.5$ & 0.164 & & \\
\hline $25(\mathrm{OH}) \mathrm{D}(\mathrm{nmol} / \mathrm{L})$ & $70.8 \pm 20.5$ & $78.2 \pm 22.1$ & 0.015 & 0.024 & $1.017(1.002-1.032)^{\dagger}$ \\
\hline 25(OH)D2 (nmol/L) & $5.2 \pm 9.1$ & $10.6 \pm 11.7$ & 0.003 & 0.027 & $1.026(1.003-1.050)^{\dagger}$ \\
\hline $25(\mathrm{OH}) \mathrm{D} 3(\mathrm{nmol} / \mathrm{L})$ & $65.5 \pm 21.0$ & $67.7 \pm 24.2$ & 0.497 & & \\
\hline
\end{tabular}

Values are presented as mean \pm standard deviation.

25(OH)D2: 25-hydroxyvitamin D2, 25(OH)D3: 25-hydroxyvitamin D3.

${ }^{*}$ Calcium and vitamin D indicate the amount taken by the diet. ${ }^{\dagger}$ p-value calculated using t-test. ${ }^{\dagger}$ p-value calculated using logistic regression for multivariate analysis.

population is the first to compare differences in vitamin D levels with prostate cancer among different races.

There have been conflicting data in terms of the prostate cancer risk according to serum vitamin D levels. Our result that there was a significant positive association between $25(\mathrm{OH}) \mathrm{D} 2$ levels and prostate cancer in non-Hispanic white males is not consistent with the results of previous studies that found that higher vitamin $\mathrm{D}$ levels have a beneficial role. ${ }^{2-4,10,11}$ However, several recent studies have found that elevated vitamin D levels increase the risk of prostate cancer. $^{5,12-14}$ The mechanisms that contribute to the associa- tion between greater $25(\mathrm{OH}) \mathrm{D}$ levels and prostate cancer development are unclear. However, we can speculate that at higher levels, $25(\mathrm{OH}) \mathrm{D}$ displaces $1,25(\mathrm{OH})_{2} \mathrm{D}$ from vitamin D binding protein. Pettifor et al. and others have found that an increase in free $1,25(\mathrm{OH})_{2} \mathrm{D}$ can result from displacement from vitamin $\mathrm{D}$ binding protein by higher $25(\mathrm{OH}) \mathrm{D}$ levels. ${ }^{15-17} 1,25(\mathrm{OH})_{2} \mathrm{D}$ inhibits cell proliferation, angiogenesis, and other metabolic activities. Therefore, the subsequently lower levels of $1,25(\mathrm{OH})_{2} \mathrm{D}$ that result from $25(\mathrm{OH}) \mathrm{D}$ binding to vitamin $\mathrm{D}$ binding protein may promote prostate cancer development. 
Table 4. Characteristics of non-Hispanic black males by prostate cancer history

\begin{tabular}{|c|c|c|c|c|}
\hline Characteristic & $\begin{array}{l}\text { Never been diagnosed with } \\
\text { prostate cancer }(n=230)\end{array}$ & $\begin{array}{l}\text { Diagnosed with prostate } \\
\text { cancer }(n=26)\end{array}$ & p-value ${ }^{\dagger}$ & p-value ${ }^{\ddagger}$ \\
\hline Age (yr) & $58.2 \pm 10.8$ & $68.8 \pm 7.3$ & $<0.001$ & $<0.001$ \\
\hline Weight $(\mathrm{kg})$ & $89.9 \pm 22.1$ & $90.1 \pm 15.5$ & 0.967 & \\
\hline Body mass index $\left(\mathrm{kg} / \mathrm{m}^{2}\right)$ & $29.1 \pm 6.7$ & $30.0 \pm 5.5$ & 0.504 & \\
\hline Total cholesterol (mg/dL) & $198.4 \pm 41.7$ & $196.2 \pm 38.8$ & 0.796 & \\
\hline Calcium $(\mathrm{mg} / \text { day })^{*}$ & $749.2 \pm 483.6$ & $637.0 \pm 339.4$ & 0.251 & \\
\hline Vitamin D $(25(\mathrm{OH}) \mathrm{D} 2+25(\mathrm{OH}) \mathrm{D} 3)^{*}(\mu \mathrm{g} /$ day $)$ & $3.3 \pm 3.3$ & $6.3 \pm 15.6$ & 0.339 & \\
\hline $25(\mathrm{OH}) \mathrm{D}(\mathrm{nmol} / \mathrm{L})$ & $43.9 \pm 18.6$ & $49.8 \pm 16.1$ & 0.122 & \\
\hline 25(OH)D2 (nmol/L) & $4.6 \pm 8.6$ & $3.5 \pm 5.3$ & 0.540 & \\
\hline $25(\mathrm{OH}) \mathrm{D} 3(\mathrm{nmol} / \mathrm{L})$ & $39.3 \pm 17.8$ & $46.2 \pm 15.9$ & 0.058 & \\
\hline
\end{tabular}

Values are presented as mean \pm standard deviation.

25(OH)D2: 25-hydroxyvitamin D2, 25(OH)D3: 25-hydroxyvitamin D3.

* Calcium and vitamin D indicate the amount taken by the diet. ${ }^{\dagger}$ p-value calculated using t-test. ${ }^{\dagger}$ p-value calculated using logistic regression for multivariate analysis.

Table 5. Characteristics of the Others group (Mexican American and Hispanic) by prostate cancer history

\begin{tabular}{|c|c|c|c|c|}
\hline Characteristic & $\begin{array}{l}\text { Never been diagnosed with } \\
\text { prostate cancer }(n=344)\end{array}$ & $\begin{array}{l}\text { Diagnosed with prostate } \\
\text { cancer }(n=5)\end{array}$ & p-value ${ }^{\dagger}$ & p-value ${ }^{\ddagger}$ \\
\hline Age (yr) & $57.0 \pm 11.4$ & $73.4 \pm 5.4$ & 0.001 & 0.011 \\
\hline Weight $(\mathrm{kg})$ & $83.0 \pm 15.8$ & $80.7 \pm 17.4$ & 0.740 & \\
\hline Body mass index $\left(\mathrm{kg} / \mathrm{m}^{2}\right)$ & $29.1 \pm 4.6$ & $29.2 \pm 4.2$ & 0.956 & \\
\hline Total cholesterol (mg/dL) & $205.6 \pm 41.8$ & $176.4 \pm 51.7$ & 0.124 & \\
\hline Calcium (mg/day)* & $909.0 \pm 572.8$ & $535.8 \pm 229.4$ & 0.147 & \\
\hline Vitamin D $(25(\mathrm{OH}) \mathrm{D} 2+25(\mathrm{OH}) \mathrm{D} 3)^{*}(\mu \mathrm{g} /$ day $)$ & $4.7 \pm 4.6$ & $2.6 \pm 3.0$ & 0.319 & \\
\hline $25(\mathrm{OH}) \mathrm{D}(\mathrm{nmol} / \mathrm{L})$ & $58.4 \pm 17.6$ & $50.1 \pm 22.5$ & 0.296 & \\
\hline 25(OH)D2 (nmol/L) & $3.5 \pm 6.0$ & $2.4 \pm 2.2$ & 0.682 & \\
\hline $25(\mathrm{OH}) \mathrm{D} 3(\mathrm{nmol} / \mathrm{L})$ & $54.9 \pm 17.2$ & $47.7 \pm 21.6$ & 0.354 & \\
\hline
\end{tabular}

Values are presented as mean \pm standard deviation.

25(OH)D2: 25-hydroxyvitamin D2, 25(OH)D3: 25-hydroxyvitamin D3.

*Calcium and vitamin D indicate the amount taken by the diet. ${ }^{\dagger}$ p-value calculated using t-test. ${ }^{\dagger}$ p-value calculated using logistic regression for multivariate analysis.

$25(\mathrm{OH}) \mathrm{D}$ consists of $25(\mathrm{OH}) \mathrm{D} 2$ and $25(\mathrm{OH}) \mathrm{D} 3$, which are the 2 significant forms of vitamin D. 25(OH)D2 have the same effects on prostate cancer growth inhibition but with fewer hypercalcemia-related side effects. Therefore, many studies have exploited the efficacy of $25(\mathrm{OH}) \mathrm{D} 2 .^{18-21}$ Some of the studies have analyzed total $25(\mathrm{OH}) \mathrm{D}$ without separating $25(\mathrm{OH}) \mathrm{D} 2$ and $25(\mathrm{OH}) \mathrm{D} 3$. Unlike previous studies, we analyzed $25(\mathrm{OH}) \mathrm{D} 2$ and $25(\mathrm{OH}) \mathrm{D} 3$ separately in this study. $25(\mathrm{OH}) \mathrm{D} 2$ (ergocalciferol) is a plant-based sterol found in fungi that occur on roughage. $25(\mathrm{OH}) \mathrm{D} 3$ (cholecalciferol) is animal-based sterol that can be obtained from vitamin supplements or from endogenous synthesis in the skin. Our study results indicated that only $25(\mathrm{OH}) \mathrm{D} 2$ level was significantly associated with prostate cancer in non-Hispanic white males. Normal and malignant prostate cells contain vitamin $\mathrm{D}$ receptor, which mediates the antiproliferative action of 1,25 $(\mathrm{OH})_{2} \mathrm{D} 3 .^{22,23}$ However, 1,25 $(\mathrm{OH})_{2} \mathrm{D} 3$ and $1,25(\mathrm{OH})_{2} \mathrm{D} 2$ have similar dose-dependent inhibition effects on prostate cancer cells. ${ }^{24}$ Therefore, we can infer that although both $25(\mathrm{OH}) \mathrm{D} 2$ and $25(\mathrm{OH}) \mathrm{D} 3$ are related to prostate cancer, the main risk factor is most likely to be $25(\mathrm{OH}) \mathrm{D} 2$ level because the differences in $25(\mathrm{OH}) \mathrm{D} 3$ are not statistically significant between those with and without prostate cancer. 25(OH)D2 and 25(OH)D3 levels have not been analyzed separately in most studies. ${ }^{1,4,5,7,12}$ Therefore, 25(OH)D2 and 25(OH)D3 should be studied in- 
Table 6. Characteristics of non-Hispanic white males without prostate cancer history ${ }^{\S}$ by prostate specific antigen (PSA) category

\begin{tabular}{|c|c|c|c|c|}
\hline Characteristic & $\begin{array}{c}\mathrm{PSA} \leq 3 \mathrm{ng} / \mathrm{mL} \\
\quad(\mathrm{n}=575)\end{array}$ & $\begin{array}{c}\mathrm{PSA}>3 \mathrm{ng} / \mathrm{mL} \\
\quad(\mathrm{n}=113)\end{array}$ & p-value ${ }^{\dagger}$ & p-value ${ }^{\ddagger}$ \\
\hline Age (yr) & $60.0 \pm 12.5$ & $71.2 \pm 8.1$ & $<0.001$ & $<0.001$ \\
\hline Weight $(\mathrm{kg})$ & $91.3 \pm 19.5$ & $85.5 \pm 17.4$ & 0.003 & 0.347 \\
\hline Body mass index $\left(\mathrm{kg} / \mathrm{m}^{2}\right)$ & $29.3 \pm 5.6$ & $28.5 \pm 5.1$ & 0.160 & \\
\hline Total cholesterol (mg/dL) & $191.1 \pm 41.1$ & $193.0 \pm 44.2$ & 0.647 & \\
\hline Calcium (mg/day)* & $983.0 \pm 595.3$ & $845.5 \pm 440.1$ & 0.005 & 0.601 \\
\hline Vitamin D $(25(\mathrm{OH}) \mathrm{D} 2+25(\mathrm{OH}) \mathrm{D} 3)^{*}(\mu \mathrm{g} /$ day $)$ & $5.0 \pm 5.3$ & $4.8 \pm 6.6$ & 0.695 & \\
\hline $25(\mathrm{OH}) \mathrm{D}(\mathrm{nmol} / \mathrm{L})$ & $4.9 \pm 9.0$ & $6.9 \pm 9.7$ & 0.046 & 0.396 \\
\hline $25(\mathrm{OH}) \mathrm{D} 2(\mathrm{nmol} / \mathrm{L})$ & $65.5 \pm 21.3$ & $67.0 \pm 19.8$ & 0.496 & \\
\hline
\end{tabular}

Values are presented as mean \pm standard deviation.

25(OH)D2: 25-hydroxyvitamin D2, 25(OH)D3: 25-hydroxyvitamin D3.

*Calcium and vitamin D indicate the amount taken by the diet. ${ }^{\dagger}$ p-value calculated using t-test. ${ }^{\dagger}$ p-value calculated using logistic regression for multivariate analysis. ${ }^{\S}$ Only non-Hispanic white males without prostate cancer history who have prostate specific antigen results available are included.

dividually, and future studies are warranted to further investigate the role of $25(\mathrm{OH}) \mathrm{D} 2$, which is just almost 10 percent of $25(\mathrm{OH}) \mathrm{D} 3$.

In Table 3, it seems that higher vitamin D levels in prostate cancer are due to the older age because the older age is the significantly associated with prostate cancer. However, because there were no significant differences in age between the vitamin D levels in Table 2, we could know that higher vitamin $\mathrm{D}$ level is not due to the older age.

In the NHANES study, PSA levels were not evaluated in men with prostate disorders, including prostate cancer; men with prostate cancer were excluded from the analysis of the relationship between vitamin D and PSA level. In our multivariate analysis, vitamin D was not associated with PSA level causing detection bias, similar to the research by Anic et al., ${ }^{25}$ which found that PSA concentration is not associated with serum 25(OH)D using NHANES 2001-2006 data.

Calcium and vitamin D intake are not associated with prostate cancer. Studies that examine the effects of vitamin $\mathrm{D}$ and calcium in different races, especially in Asian populations, are needed because few studies have been published. ${ }^{26-29}$ The relationship between adiposity and prostate cancer risk has been extensively investigated but remains unclear. The results of some studies have not supported adiposity as a risk factor for prostate cancer, but a recent meta-analysis found that there is a positive association between BMI and prostate cancer risk. ${ }^{30,31}$ However, the results of our study indicated that there was no association between BMI and prostate cancer for any race group.

This study had several limitations. First, because we used a cross-sectional study design, the presence of a causal relationship could not be evaluated. Second, the NHANES study excluded individuals with a prostate cancer from the evaluation of PSA. Therefore, a broad analysis of the relationship between PSA and vitamin D levels in prostate cancer patients could not be performed. Third, in the prostate cancer patients, all variables were measured after the prostate cancer diagnosis. However, we could not get the exact information about the interval between the prostate cancer diagnosis and the variables measurement, and the prostate cancer treatment and physical activity related to prostate cancer disease status might have affected vitamin D levels. Blood samples taken before a prostate cancer diagnosis should be used to examine the contributions of $25(\mathrm{OH}) \mathrm{D} 2$ and $25(\mathrm{OH}) \mathrm{D} 3$. Further analyses of the relationship between $25(\mathrm{OH}) \mathrm{D} 2$ and prostate cancer should be performed. Fourth, the vitamin D data were collected during the summer months in the northern latitudes and during the winter months in the southern latitudes for practical reasons. Seasonal variations in vitamin D levels could not be evaluated in this study. Fifth, positive association between 25(OH)D2 levels and prostate cancer was limited to non-Hispanic white males. Further studies with larger sample sizes in other races are required to validate our findings in non-Hispanic white males. 


\section{CONCLUSIONS}

To our knowledge, this study is the first to suggest an association between $25(\mathrm{OH}) \mathrm{D} 2$ levels and prostate cancer in non-Hispanic white males. This study revealed a positive association between vitamin $\mathrm{D}$, especially $25(\mathrm{OH}) \mathrm{D} 2$, and prostate cancer, however, vitamin D was not associated with PSA level. Further studies should be performed to investigate the role of $25(\mathrm{OH}) \mathrm{D} 2$ in prostate cancer.

\section{CONFLICT OF INTEREST}

The authors claim no conflicts of interest.

\section{REFERENCES}

1. Holick MF. Vitamin D deficiency. N Engl J Med 2007; 357:266-81.

2. Kristal AR, Till C, Song X, Tangen CM, Goodman PJ, Neuhauser ML, et al. Plasma vitamin D and prostate cancer risk: results from the Selenium and Vitamin E Cancer Prevention Trial. Cancer Epidemiol Biomarkers Prev 2014;23:1494-504.

3. Schenk JM, Till CA, Tangen CM, Goodman PJ, Song X, Torkko KC, et al. Serum 25-hydroxyvitamin D concentrations and risk of prostate cancer: results from the Prostate Cancer Prevention Trial. Cancer Epidemiol Biomarkers Prev 2014;23:1484-93.

4. Tuohimaa P, Lyakhovich A, Aksenov N, Pennanen P, Syvälä H, Lou YR, et al. Vitamin D and prostate cancer. J Steroid Biochem Mol Biol 2001;76:125-34.

5. Xu Y, Shao X, Yao Y, Xu L, Chang L, Jiang Z, et al. Positive association between circulating 25-hydroxyvitamin D levels and prostate cancer risk: new findings from an updated meta-analysis. J Cancer Res Clin Oncol 2014;140:1465-77.

6. Siegel R, Ma J, Zou Z, Jemal A. Cancer statistics, 2014. CA Cancer J Clin 2014;64:9-29.

7. Tuohimaa $\mathrm{P}$, Tenkanen L, Ahonen M, Lumme S, Jellum E, Hallmans G, et al. Both high and low levels of blood vitamin $\mathrm{D}$ are associated with a higher prostate cancer risk: a longitudinal, nested case-control study in the Nordic countries. Int J Cancer 2004;108:104-8.

8. Carroll PR, Parsons JK, Andriole G, Bahnson RR, Castle EP, Catalona WJ, et al. NCCN Guidelines Insights: Prostate Cancer Early Detection, Version 2.2016. J Natl Compr Canc Netw 2016;14:509-19.

9. Ross AC, Manson JE, Abrams SA, Aloia JF, Brannon PM, Clinton SK, et al. The 2011 report on dietary reference in- takes for calcium and vitamin D from the Institute of Medicine: what clinicians need to know. J Clin Endocrinol Metab 2011;96:53-8.

10. Fleet JC. Molecular actions of vitamin D contributing to cancer prevention. Mol Aspects Med 2008;29:388-96.

11. Holick MF. Vitamin D: its role in cancer prevention and treatment. Prog Biophys Mol Biol 2006;92:49-59.

12. Albanes D, Mondul AM, Yu K, Parisi D, Horst RL, Virtamo J, et al. Serum 25-hydroxy vitamin D and prostate cancer risk in a large nested case-control study. Cancer Epidemiol Biomarkers Prev 2011;20:1850-60.

13. Park SY, Cooney RV, Wilkens LR, Murphy SP, Henderson BE, Kolonel LN. Plasma 25-hydroxyvitamin D and prostate cancer risk: the multiethnic cohort. Eur J Cancer 2010;46:932-6.

14. Travis RC, Crowe FL, Allen NE, Appleby PN, Roddam AW, Tjønneland A, et al. Serum vitamin D and risk of prostate cancer in a case-control analysis nested within the European Prospective Investigation into Cancer and Nutrition (EPIC). Am J Epidemiol 2009;169:1223-32.

15. Pettifor JM, Bikle DD, Cavaleros M, Zachen D, Kamdar MC, Ross FP. Serum levels of free 1,25-dihydroxyvitamin D in vitamin D toxicity. Ann Intern Med 1995;122:511-3.

16. Vieth R, Pinto TR, Reen BS, Wong MM. Vitamin D poisoning by table sugar. Lancet 2002;359:672.

17. Vieth R. Vitamin D and cancer mini-symposium: the risk of additional vitamin D. Ann Epidemiol 2009;19:441-5.

18. Schwartz GG, Oeler TA, Uskoković MR, Bahnson RR. Human prostate cancer cells: inhibition of proliferation by vitamin D analogs. Anticancer Res 1994;14:1077-81.

19. Skowronski RJ, Peehl DM, Feldman D. Actions of vitamin D3, analogs on human prostate cancer cell lines: comparison with 1,25-dihydroxyvitamin D3. Endocrinology 1995; 136:20-6.

20. Liu G, Oettel K, Ripple G, Staab MJ, Horvath D, Alberti $\mathrm{D}$, et al. Phase I trial of 1alpha-hydroxyvitamin $\mathrm{d}(2)$ in patients with hormone refractory prostate cancer. Clin Cancer Res 2002;8:2820-7.

21. Osborn JL, Schwartz GG, Smith DC, Bahnson R, Day R, Trump DL. Phase II trial of oral 1,25-dihydroxyvitamin D (calcitriol) in hormone refractory prostate cancer. Urol Oncol 1995;1:195-8.

22. Ahonen MH, Tenkanen L, Teppo L, Hakama M, Tuohimaa P. Prostate cancer risk and prediagnostic serum 25-hydroxyvitamin D levels (Finland). Cancer Causes Control 2000;11:847-52.

23. Miller GJ, Stapleton GE, Ferrara JA, Lucia MS, Pfister S, Hedlund TE, et al. The human prostatic carcinoma cell line LNCaP expresses biologically active, specific receptors for 1 alpha,25-dihydroxyvitamin D3. Cancer Res 1992;52: 515-20.

24. Chen TC, Schwartz GG, Burnstein KL, Lokeshwar BL, 
Holick MF. The in vitro evaluation of 25-hydroxyvitamin D3 and 19-nor-1alpha,25-dihydroxyvitamin D2 as therapeutic agents for prostate cancer. Clin Cancer Res 2000; 6:901-8.

25. Anic GM, Albanes D, Rohrmann S, Kanarek N, Nelson WG, Bradwin G, et al. Association between serum 25-hydroxyvitamin D and serum sex steroid hormones among men in NHANES. Clin Endocrinol (Oxf) 2016;85: 258-66.

26. Chan JM, Giovannucci E, Andersson SO, Yuen J, Adami HO, Wolk A. Dairy products, calcium, phosphorous, vitamin D, and risk of prostate cancer (Sweden). Cancer Causes Control 1998;9:559-66.

27. Tzonou A, Signorello LB, Lagiou P, Wuu J, Trichopoulos D, Trichopoulou A. Diet and cancer of the prostate: a case-control study in Greece. Int J Cancer 1999;80:704-8.
28. Rodriguez C, McCullough ML, Mondul AM, Jacobs EJ, Fakhrabadi-Shokoohi D, Giovannucci EL, et al. Calcium, dairy products, and risk of prostate cancer in a prospective cohort of United States men. Cancer Epidemiol Biomarkers Prev 2003;12:597-603.

29. Yoo C, Kim CS. Complementary and Alternative Medicine(CAM) in Urology. Korean J Urol 2008;49:193202.

30. Wright ME, Chang SC, Schatzkin A, Albanes D, Kipnis $\mathrm{V}$, Mouw $\mathrm{T}$, et al. Prospective study of adiposity and weight change in relation to prostate cancer incidence and mortality. Cancer 2007;109:675-84.

31. MacInnis RJ, English DR. Body size and composition and prostate cancer risk: systematic review and meta-regression analysis. Cancer Causes Control 2006;17:9891003. 